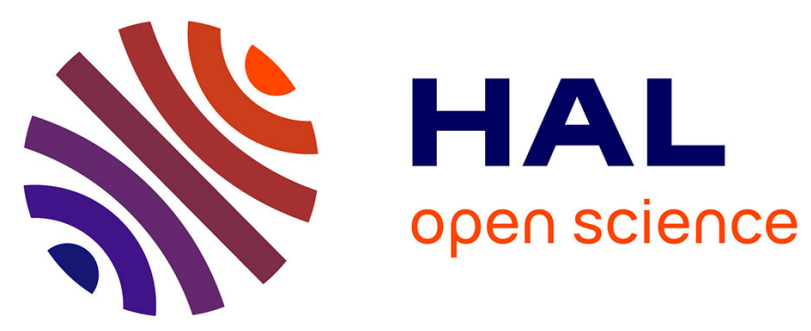

\title{
Effects of conventional, extensive and semi-intensive green roofs on building conductive heat fluxes and surface temperatures in winter in Paris \\ Patrick Stella, Erwan Personne
}

\section{To cite this version:}

Patrick Stella, Erwan Personne. Effects of conventional, extensive and semi-intensive green roofs on building conductive heat fluxes and surface temperatures in winter in Paris. Building and Environment, 2021, 205, 10.1016/j.buildenv.2021.108202 . hal-03320524

\section{HAL Id: hal-03320524 \\ https://hal.inrae.fr/hal-03320524}

Submitted on 16 Aug 2021

HAL is a multi-disciplinary open access archive for the deposit and dissemination of scientific research documents, whether they are published or not. The documents may come from teaching and research institutions in France or abroad, or from public or private research centers.
L'archive ouverte pluridisciplinaire HAL, est destinée au dépôt et à la diffusion de documents scientifiques de niveau recherche, publiés ou non, émanant des établissements d'enseignement et de recherche français ou étrangers, des laboratoires publics ou privés.

\section{(1) (1) $\$$}

Distributed under a Creative Commons Attribution - NonCommercial - NoDerivatives $\mid 4.0$ 


\section{Effects of conventional, extensive and semi-intensive green roofs}

2 on building conductive heat fluxes and surface temperatures in

\section{winter in Paris}

\section{P. Stella ${ }^{1, *}$ and E. Personne ${ }^{2}$}

[1] Université Paris-Saclay, INRAE, AgroParisTech, UMR SADAPT, 75005, Paris, France

[2] Université Paris-Saclay, INRAE, AgroParisTech, UMR ECOSYS, 78850, ThivervalGrignon, France

[*] Correspondence to: P. Stella (patrick.stella@,agroparistech.fr)

\section{Highlights}

11 Conventional, extensive and semi-intensive green roofs have been compared.

12 - Green roofs reduced temperature and heat flux fluctuations at the building surface.

13 - Deeper substrates reduced the temperature and heat flux fluctuations of the building 14 surface.

15 - On average there was no or only slight effects on winter surface urban heat island.

\section{Abstract}

This study investigated the impacts of extensive and semi-intensive green roofs on both building insulation and surface urban heat island effect under winter conditions. To this aim we compared measurements of surface and building envelope temperatures as well as conductive heat fluxes reaching the external building envelope with those measured on a conventional bituminous roof under identical climatic conditions. The main effect of green roofs was to decrease daily fluctuations of external building envelope temperatures and as a consequence to reduce fluctuations of conductive heat fluxes reaching the building envelope. This effect is all the more important that the substrate is deep, in link with its heat capacity and thermal inertia. 
26 Yet, no significant effect of the green roofs on surface urban heat island has been observed on

27 average despite a surface cooling during daytime. It is concluded that the green roofs can be 28 suitable urban greening solutions since they do not have negative effect on surface urban heat

29 island during winter, provide cooling during summer, and contribute to building insulation 30 inducing therefore building energy savings.

31

32 Keywords

33 Green roofs; building insulation; urban heat island; conductive heat fluxes; winter conditions. 


\section{1 - INTRODUCTION}

Urban areas and land-use changes lead to severe environmental issues due to urbanization. On the one hand, urban areas are strong contributors to greenhouse gas (GHG) emissions at the global scale and therefore to global warming. It is estimated that buildings are responsible for 19\% of all global 2010 energy-related GHG emissions, mainly indirect ones from electricity use. Yet, buildings account for $32 \%$ of total global final energy use, space heating and cooling representing more than one third of total building final energy consumption [1]. On the other hand, at the local scale the land-use modifications due to urbanization alter the urban microclimate and induce the so-called "urban heat island" (UHI) effect $[2,3]$ which reflects the fact that cities are warmer than their surroundings. It has numerous impacts on building energy consumption (e.g., [4-5]), citizen comfort and health (e.g., [6-8]), and urban air quality (e.g., [4, 9-10]). This phenomenon originates from the alteration of radiative budget and energy balance, in which the heat released by anthropogenic activities is a strong contributor to UHI effect. Indeed, anthropogenic heat release occurs mainly through building cooling and heating (e.g., [11]) and is responsible for an increase in urban air temperatures between 0.2 and $2.5^{\circ} \mathrm{C}$ (e.g., $[12,13])$. Within this context, the building insulation assessment allows (i) to mitigate UHI effect (through the decrease of anthropogenic heat release) and its related deleterious effects at the local scale, (ii) subsequent monetary savings, and (iii) to reduce the GHG emissions at the global scale [1].

Among the numerous techniques to improve building insulation (e.g., insulation layer depth, new insulation materials) (e.g., [14-17]), green roofs currently receive strong attention. Additionally to building insulation, they contribute to the assessment of urban air quality (e.g., $[18,19])$, the water retention to prevent runoff events (e.g., [19-21]), sound reduction and insulation, ecological preservation (e.g., [21,22]), and last but not least direct UHI mitigation owing to their capability to refresh air throughout evapotranspiration (e.g., $[23,24])$. 
Green roofs i.e., vegetated systems covering a building rooftop, are typically composed by some layers aiming to protect the building envelope (i.e., waterproofing membrane, root barrier, drainage layer), a growing medium (or substrate) layer, and a vegetation layer. It is distinguished the extensive, semi-intensive, and intensive green roofs, each characterized by the substrate thickness and plant communities [25]. Owing to plant shading, evaporative cooling, and additional insulation, green roofs help to reduce directly building energy consumption but also indirectly through UHI mitigation. However, the thermal performance of green roofs is highly variable according to the substrate and vegetation characteristics, building characteristics, and local climatic conditions. (e.g., [26-30]).

Many studies focused their attention on the impacts of green roofs on building insulation and building thermal performance, as well as on UHI mitigation, under summer conditions (e.g., $[24,28,31-35])$. Overall, it is consensual that green roofs reduce surface and air temperatures, diminish heat fluxes entering inside the building, and therefore decrease energy consumption for cooling. However, the impact of green roofs under winter conditions received less attention, and is still under debate. For instance, Santamouris et al. [36] did not found any significant effect of green roof on heating load variation under winter Mediterranean climate, while Jaffal et al. [28] reported positive impact of extensive green roofs under temperate oceanic climatic conditions. Yet, during heating period, Coma et al. [37] reported a negative impact of extensive green roof on building energy consumption under continental climate conditions, whereas under similar climatic conditions Lundholm et al. [38] found lower net heat losses from extensive green compared to conventional roofs. Moreover, experimental studies carried out under winter conditions mainly considered only one kind of green roofs, often extensive ones [37-46], without comparing the extensive, semi-intensive, and intensive green roofs together. Last, considering that winter UHI would be positive concerning building energy consumption, in particular by reducing the indoor and outdoor temperature difference, surface (and 
consequently air) cooling by green roofs would be deleterious. This issue has not been explored yet.

The objectives of this study are (i) to analyze how green roofs affect winter thermal fluxes reaching the building envelope, (ii) to determine their impact on winter surface UHI, and (iii) to compare extensive and semi-intensive green roofs under winter oceanic climatic conditions, from an experimental approach.

\section{2 - MATERIALS AND METHODS}

\section{1 - Site description}

The experiment was carried out from $1^{\text {st }}$ November 2018 to $28^{\text {th }}$ January 2019 in Paris, France. The climate is oceanic and characterized by overall cool winter. The experiment was performed on the building rooftop of AgroParisTech, higher education and research institute located in the $5^{\text {th }}$ district of Paris $\left(48^{\circ} 50^{\prime} 24^{\prime} \mathrm{N}, 2^{\circ} 20^{\prime} 55^{\prime \prime} \mathrm{E}\right)$. It is a Haussmannian building built during the $19^{\text {th }}$ century. The rooftop area is about $900 \mathrm{~m}^{2}$ and is exposed to direct solar radiation without shadowing effect from other buildings. The indoor spaces consisted in office rooms. Since the indoor uses are similar for the three roofs, the indoor conditions (especially indoor temperatures) did not differ between each roofs. The heating system only consisted in individual heater alimented by a common boiler, and no central temperature heating regulating system existed.

The experiment was performed on three different areas: the reference roof (REF) and the extensive (EXT) and semi-intensive (SI) green roofs. The reference is a conventional roof with a black bituminous waterproof membrane installed directly on the concrete slab. The green roofs are installed directly on the bituminous waterproof membrane and consisted in a root barrier, a substrate layer (13 cm for EXT, $27 \mathrm{~cm}$ for SI), and a vegetation layer (sparse Sedum 
108 for EXT; dense grass for SI) (Figure 1). For the EXT green roof, plant coverage accounted for $22 \%$ while it was close to $100 \%$ for the SI green roof.
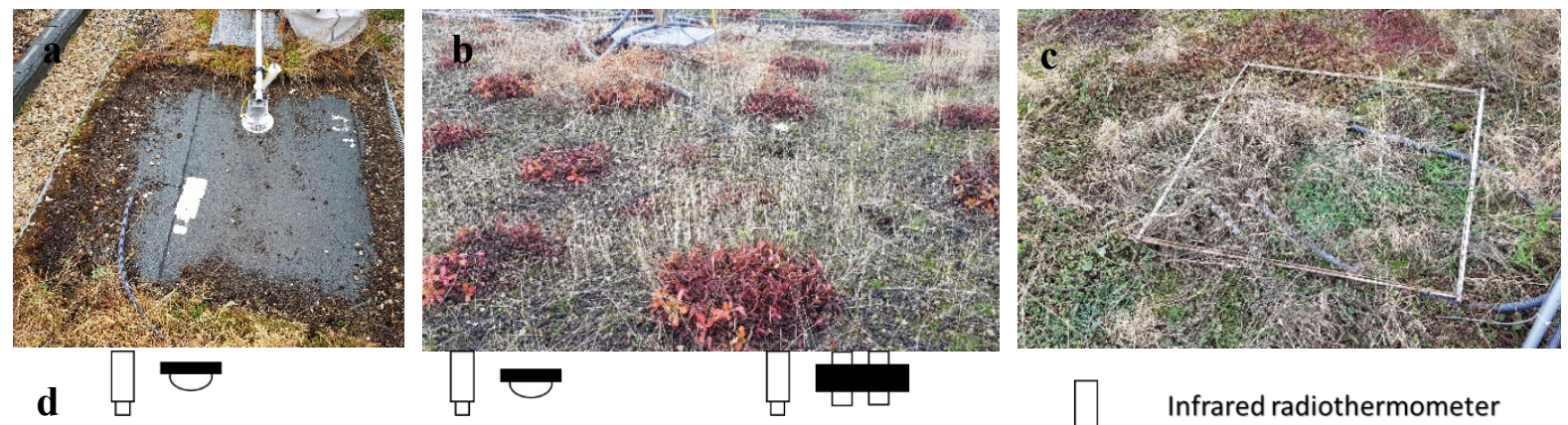

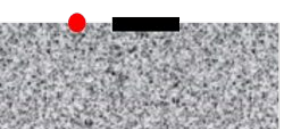

REF

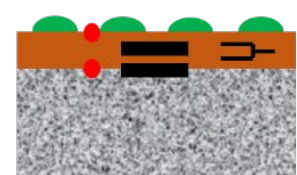

EXT

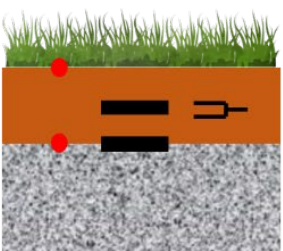

SI

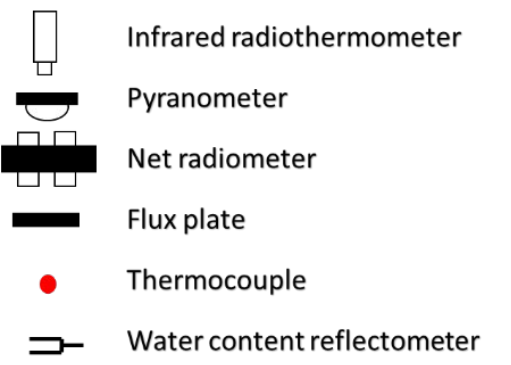

110

Figure 1: (a) The reference roof and vegetation covering the (b) extensive and (c) semi-

111 intensive green roofs. (d) Scheme of the experimental set-up and measurements on the 112 conventional (REF), extensive (EXT) and semi-intensive (SI) green roofs.

\section{2 - Instrumentation and measurements}

115 For each roof, the mean surface temperature was measured by an infrared radiothermometer

116 (IR120, Campbell Scientific Ltd, UK) installed on a mast at $1.05 \mathrm{~m}$ height above the REF roof 117 and $2 \mathrm{~m}$ height above EXT and SI green roofs. The surface measured by the sensor (half-angle 118 of view of $20^{\circ}$ ) was therefore $0.4 \mathrm{~m}^{2}$ for the REF roof and $1.6 \mathrm{~m}^{2}$ for the EXT and SI green 119 roofs. Additionally, each component of the radiative budget (i.e., incoming and outgoing short120 and longwave radiations) were measured with a net radiometer (CNR4, Kipp \& Zonen, NL) 121 above the SI green roof, while only the outgoing (i.e., reflected) shortwave radiation was 122 measured with a pyranometer (CMP11, Kipp \& Zonen, NL) above the REF and EXT roofs. 123 Moreover, five thermocouples (Type T, TC Direct, FR) were installed to provide temperature 124 measurements: on the black bituminous membrane for the REF roof and on the substrate and at 
125 the substrate-building envelope interface for both green roofs. Conductive heat fluxes inside

126 the substrate (installed at $6.5 \mathrm{~cm}$ and $13 \mathrm{~cm}$ depth for EXT and SI green roofs, respectively)

127 and outside the building envelope (i.e., installed directly on the bituminous membrane for the

128 REF roof and at the substrate-building envelope interface for both green roofs) were also

129 measured by heat flux plates (HFP01, Hukseflux, NL). Finally, water content reflectometers

130 (CS655, Campbell Scientific Ltd, UK), installed at $6.5 \mathrm{~cm}$ and $13 \mathrm{~cm}$ depth for EXT and SI

131 green roofs, respectively, provided measurements of volumetric substrate water content (Figure

132 1d). All the sensors were connected to a datalogger (CR1000X, Campbell Scientific Ltd, UK)

133 coupled with two multiplexers (AM16/32, Campbell Scientific Ltd, UK). Measurements were

134 averaged online over 30 min periods.

135 Additionally, standard meteorological conditions were measured at $2.5 \mathrm{~m}$ height above the roof

136 by several sensors installed on a mast located on the roof at around $50 \mathrm{~m}$ from the experimental

137 area: air temperature and relative humidity (HMP45C, Vaisala, FI), and rainfall (TE525WS,

138 Campbell Scientific Ltd, UK). They were measured, averaged, and recorded every 30 min on a

139 datalogger (CR1000, Campbell Scientific Ltd, UK).

140 The ranges and accuracies of the sensors used during the experiment are given Table 1.

142 Table 1: List of sensors, their range and accuracy used during the experiment

\begin{tabular}{|c|c|c|c|}
\hline Measured variable & Sensor & Range & Accuracy \\
\hline $\begin{array}{l}\text { Mean surface } \\
\text { temperature }\end{array}$ & $\begin{array}{l}\text { Infrared } \\
\text { radiothermometer IR120 }\end{array}$ & -25 to $+60^{\circ} \mathrm{C}$ & $\pm 0.2^{\circ} \mathrm{C}$ \\
\hline Temperature & Thermocouple Type T & -50 to $+150^{\circ} \mathrm{C}$ & $\pm 0.1^{\circ} \mathrm{C}$ \\
\hline $\begin{array}{l}\text { Air temperature and } \\
\text { relative humidity }\end{array}$ & $\begin{array}{l}\text { Thermo-hygrometer } \\
\text { HMP45C }\end{array}$ & $\begin{array}{l}-39 \text { to }+60^{\circ} \mathrm{C} \\
0.8 \text { to } 100 \%\end{array}$ & $\begin{array}{c} \pm 0.2^{\circ} \mathrm{C} \\
\pm 1 \%\end{array}$ \\
\hline Shortwave radiation & $\begin{array}{l}\text { Net radiometer CNR4 } \\
\text { Pyranometer CMP11 }\end{array}$ & $\begin{array}{l}0 \text { to } 2000 \mathrm{~W} \cdot \mathrm{m}^{2} \\
0 \text { to } 4000 \mathrm{~W} \cdot \mathrm{m}^{2}\end{array}$ & $\begin{array}{l} \pm 10 \% \\
<2 \%\end{array}$ \\
\hline Longwave radiation & Net radiometer CNR4 & {$[-]$} & $<10 \%$ \\
\hline Conductive heat flux & Heat flux plate HFP01 & \pm 2000 W.m ${ }^{-2}$ & $\begin{array}{l}-15 \text { to }+5 \% \\
\text { according to the } \\
\text { material in contact }\end{array}$ \\
\hline $\begin{array}{l}\text { Substrate water } \\
\text { content }\end{array}$ & Reflectometer CS655 & 0 to $100 \%$ & $\pm 3 \%$ \\
\hline
\end{tabular}




\begin{tabular}{lcc} 
Rainfall & Rain gauge TE525WS & $\begin{array}{c}-3.5 \text { to }+1 \% \\
\text { according the } \\
\text { intensity of rainfall }\end{array}$ \\
\hline
\end{tabular}

143

\section{3 - RESULTS AND DISCUSSION}

\section{1 - Overview of weather conditions}

146 During our experiment, weather conditions were representative of the winter climate in Paris.

147 Both daily and day-to-day variability of the weather conditions are reported through the half-

148 hourly and daily statistics, respectively, in Figure 2 and Table 2. The cumulated solar radiation

149 over the experimental period was $257 \mathrm{MJ} \cdot \mathrm{m}^{-2}$ over the 83 days of the experiment (Table 2). The

150 incident solar radiation followed a typical trend by increasing during the morning to reach its

151 maximum at noon, on average around $150 \mathrm{~W} \cdot \mathrm{m}^{-2}$, before decreasing during the afternoon to its

152 minimum and nocturnal value at $0 \mathrm{~W} \cdot \mathrm{m}^{-2}$ (Figure 2a). Its intensity was weak: half-hourly solar

153 radiation was $145 \pm 88 \mathrm{~W} \cdot \mathrm{m}^{-2}$ on average and varied overall between $75 \mathrm{~W} \cdot \mathrm{m}^{-2}$ and $198 \mathrm{~W} \cdot \mathrm{m}^{-}$

$154^{2}$, as indicated by the $1^{\text {st }}$ and $3^{\text {rd }}$ quartiles respectively. However, some sunny days occurred, as

155 indicated by the maximum half-hourly solar radiation $\left(520 \mathrm{~W} \cdot \mathrm{m}^{-2}\right)$. At the daily scale, mean

156 solar radiation was only $127 \pm 61 \mathrm{~W} \cdot \mathrm{m}^{-2}$ and daily mean solar intensity usually ranged between

$15778 \mathrm{~W} \cdot \mathrm{m}^{-2}$ and $183 \mathrm{~W} \cdot \mathrm{m}^{-2}$ with a minimum and maximum at $51 \mathrm{~W} \cdot \mathrm{m}^{-2}$ and $256 \mathrm{~W} \cdot \mathrm{m}^{-2}$,

158 respectively (Table 2). Air temperature and relative humidity exhibited an inverse correlation.

159 Air temperature increased from its minimum, on average $6.3^{\circ} \mathrm{C}$ just before the sunrise, to its

160 maximum in early afternoon, on average $8.7^{\circ} \mathrm{C}$, and then decreased progressively during the

161 afternoon and the night. Conversely, air relative humidity decreased from its maximum at the

162 sunrise, around $87 \%$ on average, to its minimum, around $77 \%$ on average, reached in early

163 afternoon, and finally increased in the afternoon and during nighttime (Figure 2b). Few

164 particularly dry and warm days for the season occurred with maximum half-hourly and daily

165 mean temperatures of $19.5^{\circ} \mathrm{C}$ and $15.3^{\circ} \mathrm{C}$, respectively, and minimum half-hourly and daily

166 mean air relative humidity of $40 \%$ and $65 \%$, respectively. Some cold events also occurred, with 
167 negative minimum half-hourly and mean daily air temperatures. Overall, climatic conditions 168 were cold and wet as indicated by mean and median values, around $7.4-7.8^{\circ} \mathrm{C}$ and $84-86 \%$ for 169 air temperature and relative humidity respectively, both at the half-hourly and daily scales.

170 (Table 2). Yet, rainfall events regularly occurred: 51 days with at least one rainfall event were 171 recorded corresponding to 337 half-hourly events over the whole experimental period. On 172 average, rainfall events were $0.46 \mathrm{~mm}$ and $3.02 \mathrm{~mm}$ at the half-hourly and daily scales, 173 respectively, but some exceptional and strong episodes appeared, $2.6 \mathrm{~mm}$ at the half-hourly 174 scale and $14.2 \mathrm{~mm}$ at the daily scale on maximum. Over the three months of the experiment the 175 cumulated rainfall was $154.2 \mathrm{~mm}$ (Table 2). As a consequence, green roof did not suffer from 176 water limitation, mean substrate water content $\left(0.29 \mathrm{~m}^{3} \cdot \mathrm{m}^{-3}\right.$ and $0.14 \mathrm{~m}^{3} \cdot \mathrm{m}^{-3}$ for EXT and SI 177 green roofs, respectively) being close to their maximum $\left(0.46 \mathrm{~m}^{3} \cdot \mathrm{m}^{-3}\right.$ and $0.19 \mathrm{~m}^{3} \cdot \mathrm{m}^{-3}$ EXT and 178 SI green roofs, respectively). Yet, the regular rainfall events allowed a quite stable substrate 179 water content over the period for both EXT and SI green roofs, as indicated by the weak range 180 of variations between $1^{\text {st }}$ and $3^{\text {rd }}$ quartiles of the substrate water contents $(0.25$ to 0.32 for EXT 181 green roof; 0.13 to 0.16 for SI green roof) (Table 2). As a consequence, the effect of soil water 182 content variations on temperatures and conductive heat fluxes could be excluded. 

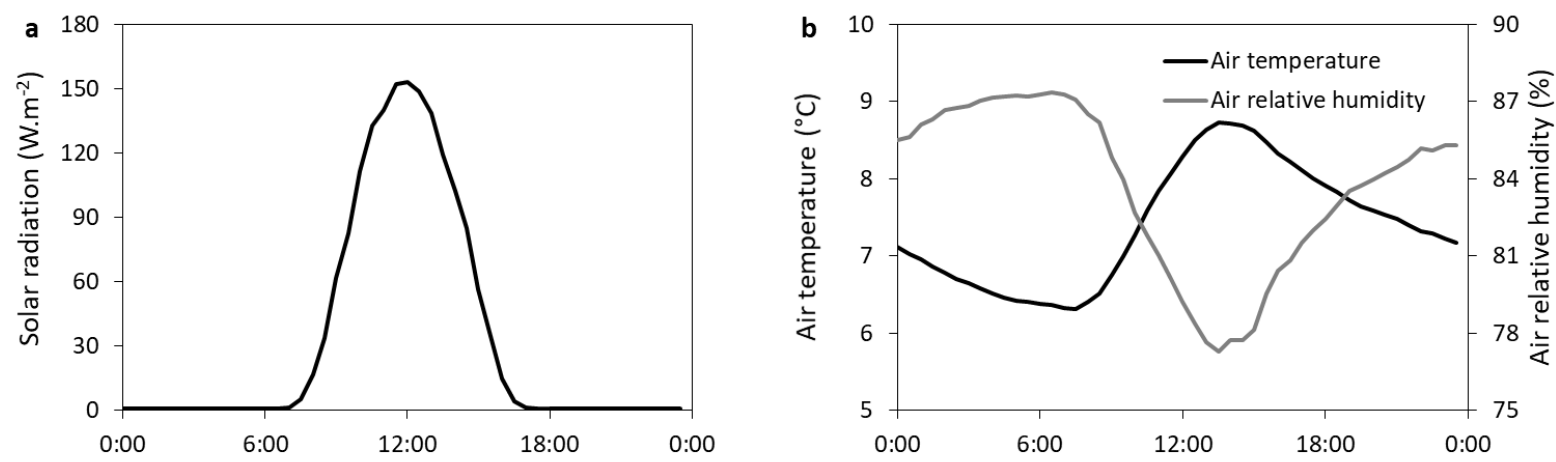

183
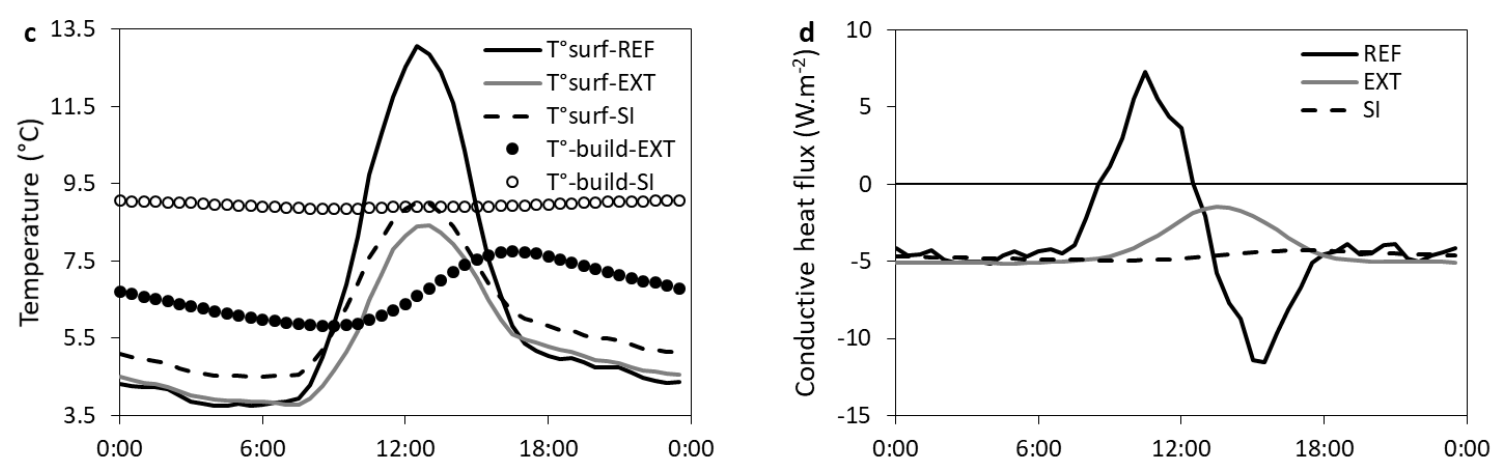

184 Figure 2: Half hourly means of (a) solar radiation, (b) air temperature (black line) and relative

185 humidity (grey line), (c) surface temperatures of the reference ( $\mathrm{T}^{\circ}$-surf-REF; black line),

186 extensive $\left(\mathrm{T}^{\circ}\right.$-surf-EXT; grey line), and semi-intensive $\left(\mathrm{T}^{\circ}\right.$-surf-SI; dashed black line) roofs,

187 and temperatures at the substrate-building envelope interface for extensive $\left(\mathrm{T}^{\circ}\right.$-build-EXT;

188 filled circles) and semi-intensive ( $\mathrm{T}^{\circ}$ build-SI; open circles) green roofs, and (d) conductive heat

189 flux outside the building envelope for the reference (REF; black line), extensive (EXT; grey

190 line), and semi-intensive (SI; dashed black line).

191 
192 Table 2: Half-hourly and daily means ( \pm standard deviations), medians, minimums,

193 maximums, and $1^{\text {st }}$ and $3^{\text {rd }}$ quartiles of solar radiation, air temperature, air relative humidity,

194 rainfall events, and substrate water content for extensive and intensive green roofs. The number

195 of rainfall events (n) and cumulated rainfall over the experimental period are also given

\begin{tabular}{|c|c|c|c|c|c|c|c|}
\hline & & \multirow[t]{2}{*}{$\begin{array}{c}\text { Solar } \\
\text { radiation } \\
\mathrm{W} . \mathrm{m}^{-2}\end{array}$} & \multirow[t]{2}{*}{$\begin{array}{c}\text { Air } \\
\text { temperature } \\
{ }^{\circ} \mathrm{C}\end{array}$} & \multirow[t]{2}{*}{$\begin{array}{c}\text { Air relative } \\
\text { humidity } \\
\%\end{array}$} & \multirow[t]{2}{*}{$\begin{array}{l}\text { Rainfall } \\
\text { events } \\
\text { mm }\end{array}$} & \multicolumn{2}{|c|}{$\begin{array}{l}\text { Substrate water content } \\
\qquad \mathrm{m}^{3} \cdot \mathrm{m}^{-3}\end{array}$} \\
\hline & & & & & & Extensive & $\begin{array}{c}\text { Semi- } \\
\text { intensive }\end{array}$ \\
\hline \multirow{7}{*}{ 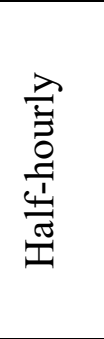 } & Mean \pm SD & $145 \pm 88$ & $7.4 \pm 3.9$ & $84 \pm 10$ & $0.46 \pm 0.37$ & $0.29 \pm 0.03$ & $0.14 \pm 0.03$ \\
\hline & Min & 0 & -2.4 & 40 & 0.2 & 0.15 & 0.03 \\
\hline & $1^{\text {st }}$ quartile & 75 & 4.8 & 77 & 0.2 & 0.25 & 0.13 \\
\hline & Median & 115 & 7.7 & 86 & 0.2 & 0.29 & 0.15 \\
\hline & $3^{\text {rd }}$ quartile & 198 & 10.3 & 92 & 0.6 & 0.32 & 0.16 \\
\hline & Max & 520 & 19.5 & 99 & 2.6 & 0.46 & 0.19 \\
\hline & $\mathrm{n}$ & - & - & - & 337 & - & - \\
\hline \multirow{7}{*}{$\stackrel{\lambda}{\stackrel{\lambda}{\overparen{D}}}$} & Mean \pm SD & $127 \pm 61$ & $7.4 \pm 3.7$ & $84 \pm 8$ & $3.02 \pm 3.20$ & $0.29 \pm 0.06$ & $0.14 \pm 0.03$ \\
\hline & Min & 51 & -0.3 & 65 & 0.2 & 0.16 & 0.03 \\
\hline & $1^{\text {st }}$ quartile & 78 & 4.9 & 79 & 0.8 & 0.25 & 0.13 \\
\hline & Median & 106 & 7.8 & 84 & 2.0 & 0.28 & 0.15 \\
\hline & $3^{\text {rd }}$ quartile & 183 & 10.2 & 90 & 4.2 & 0.33 & 0.16 \\
\hline & $\operatorname{Max}$ & 256 & 15.3 & 97 & 14.2 & 0.43 & 0.17 \\
\hline & $\mathrm{n}$ & - & - & - & 51 & - & - \\
\hline$\frac{0}{0} \cdot \frac{7}{0}$ & Sum & $\begin{array}{c}257 \\
\text { MJ.m }\end{array}$ & - & - & 154.2 & - & - \\
\hline
\end{tabular}

\section{2 - Albedo values of conventional and green roofs}

198 The albedos for conventional and green roofs were determined by linear regressions between

199 the measured incident and reflected shortwave solar radiations, albedos being given by the 200 slopes of the regression lines. The SI green roof exhibited the largest albedo (0.16) while the

201 EXT green roof had the weakest one (0.12). The REF roof showed an intermediate albedo (0.15)

202 but also the most variable as indicated by the coefficient of determination of the relationships $203\left(\mathrm{R}^{2}=0.82\right)$. Albedo variability was the weakest for the SI green roof $\left(\mathrm{R}^{2}=0.95\right)$ and 204 intermediate for EXT green roof $\left(\mathrm{R}^{2}=0.90\right)$ (Figure 3). 
205 Whereas Radhi et al. [47] reported largest albedo (0.23) for bituminous membrane, the albedo 206 for the REF roof determined experimentally is consistent with the typical range, 0.1-0.2, found 207 for bitumen roofs [48]. For the green roofs, although previous studies did not distinguished 208 between their different kinds i.e., extensive, semi-intensive or intensive, Lazzarin et al. [39] 209 reported green roof albedo of 0.23 and Takebayashi and Moriyama [49] determined soil and 210 grass albedos of 0.225 and 0.21 , respectively, for dry surface conditions. The albedos for EXT 211 and SI green roofs are lower than these studies, but consistent with the results obtained by 212 D'Orazio et al. [42] who measured green roof albedo of 0.13 . On the one hand, these weak 213 albedos for green roofs compared to those reported in previous studies can be explained first 214 by the season of the experiment. While previous studies were carried out under spring and 215 summer conditions implying green and fully developed canopy cover, the winter season implies 216 brown and less developed vegetation. It induces that the vegetation albedo is lower, and the soil 217 (typically a dark material) albedo contributes more to total green roof albedo. It also probably 218 explains the lowest albedo for the EXT green roof than for the SI green roof: since vegetation 219 is sparser, the lower soil albedo contributes more to the total EXT green roof albedo than for 220 the SI green roof. On the other hand, wetter conditions during winter than during spring and 221 summer induces darker color of the soil surface and bituminous membrane leading to lower 222 albedos. This issue could also explain the large variability of albedo for the REF roof and EXT 223 green roof which would reflect the wetting and drying of the surface alternately during the 224 experiment. 


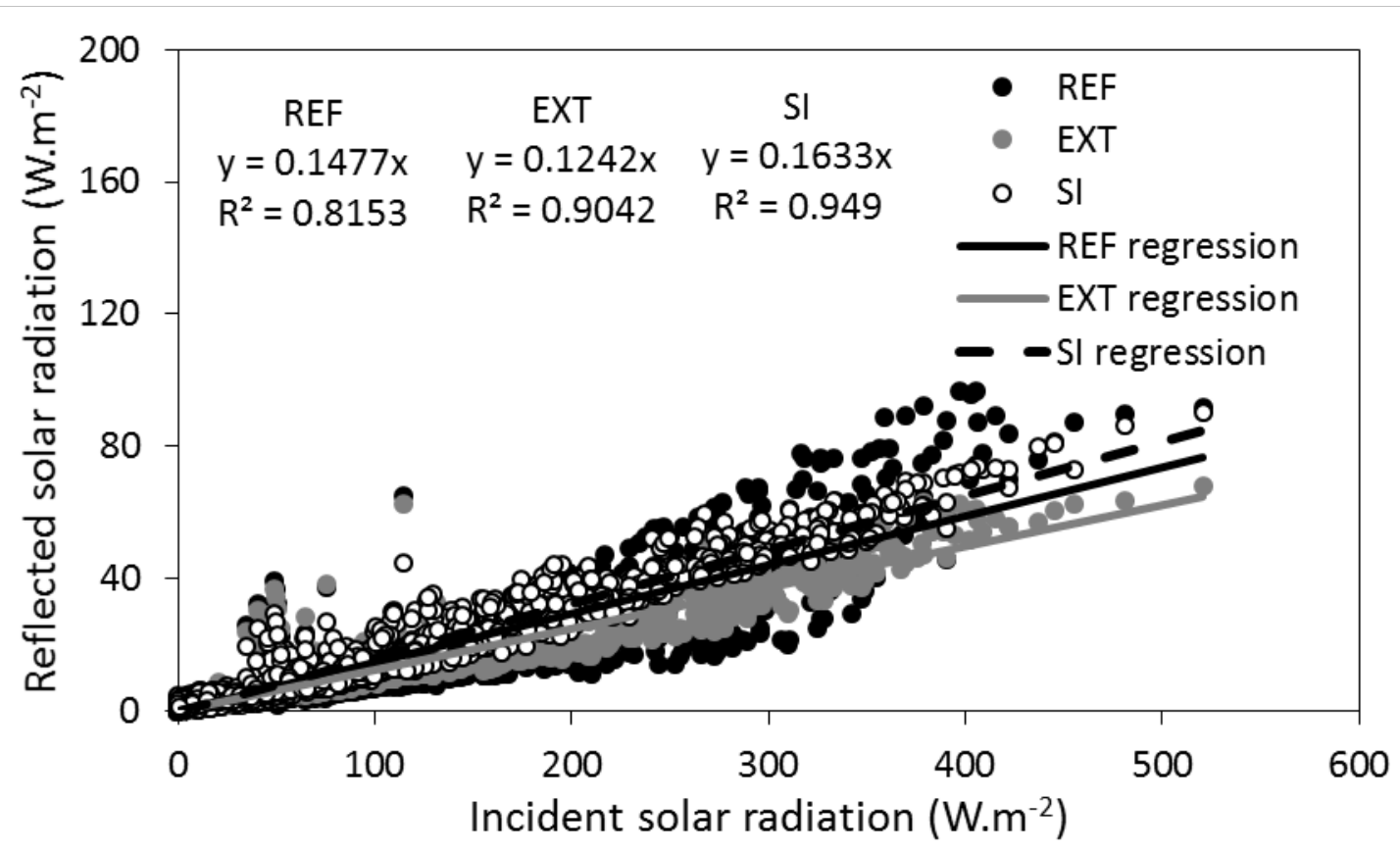

226 Figure 3: Relationships between incident and reflected solar radiation for the reference (REF;

227 black symbols), extensive (EXT; grey symbols), and semi-intensive (SI; open symbols) roofs.

228 Black, grey, and dashed black lines are regressions for REF, EXT, and SI roofs, respectively.

\section{3 - Impact of green roofs on building insulation}

231 In order to evaluate the impact of the green roofs on building insulation, temperatures and

232 conductive heat fluxes at the building surface (corresponding to surface temperature for the

233 REF roof and temperature at the substrate-building envelope interface for green roofs) have

234 been analyzed and compared between REF, EXT and SI roofs.

235 For the REF roof, the building surface temperature exhibited the largest fluctuation and 236 followed the dynamic of solar radiation by increasing during the morning to reach its maximum 237 around noon, on average around $13^{\circ} \mathrm{C}$, before decreasing during the afternoon to its minimum 238 and nocturnal value at $3.5-5^{\circ} \mathrm{C}$ (Figure $2 \mathrm{c}$ ). Over the whole experimental period median 239 building surface temperature was $6.4^{\circ} \mathrm{C}$, typically ranged from $2.6^{\circ} \mathrm{C}$ to $9.5^{\circ} \mathrm{C}\left(1^{\text {st }}\right.$ and $3^{\text {rd }}$ 240 quartiles), and up to -7.2 to 19.8 for the minimum and maximum values (Figure $4 \mathrm{a}$ ). The 241 conductive heat fluxes reaching the building envelope strongly varied across the day. During 
nighttime, mean half hourly fluxes were negative indicating heat losses from the building,

243 around $-5 \mathrm{~W} . \mathrm{m}^{-2}$. It increased from sunrise to reach its maximum (around $7 \mathrm{~W} . \mathrm{m}^{-2}$ ) in late

244 morning, and decreased until middle afternoon to its minimum $\left(-11 \mathrm{~W} \cdot \mathrm{m}^{-2}\right)$. Finally it increased

245 until sunset to reach its nocturnal value. The building therefore lost heat most of the time,

246 excepted during a short period during the morning for which building gained heat as indicated

247 by the positive values (Figure $2 \mathrm{~d}$ ).

248 Considering only the whole period the EXT green roof exhibited similar median building

249 surface temperature $\left(7^{\circ} \mathrm{C}\right)$ and $1^{\text {st }}$ and $3^{\text {rd }}$ quartiles $\left(3.6^{\circ} \mathrm{C}\right.$ and $9.4^{\circ} \mathrm{C}$, respectively) to those

250 observed for the REF roof (Figure 4a). However building surface temperature for EXT green

251 roof exhibited less fluctuations than REF roof as indicated by both their minimum and 252 maximum values $\left(0.4^{\circ} \mathrm{C}\right.$ and $15.7^{\circ} \mathrm{C}$, respectively; Figure $\left.4 \mathrm{a}\right)$ and its daily pattern (Figure 2c).

253 Indeed the minimal mean half hourly building surface temperature was $6^{\circ} \mathrm{C}$ and occurred only

254 in late morning. It reached its maximum, around $8^{\circ} \mathrm{C}$, in late afternoon and continuously

255 decreased during nighttime (Figure 2c). Hence, the building surface for EXT green roof was

256 warmer than for REF roof most of the time, excepted between 9:00 and 15:00 for which it was

257 cooler (Figure 2c). The temperature difference between REF and EXT roofs typically ranged

258 between $-3.1^{\circ} \mathrm{C}\left(1^{\text {st }}\right.$ quartile $)$ and $1.2^{\circ} \mathrm{C}\left(3^{\text {rd }}\right.$ quartile $)$, overall at $-0.8^{\circ} \mathrm{C}$ (median) indicating that

259 the building surface was slightly warmer for the EXT green roof than for the REF roof.

260 However, the building surface for the EXT green roof could be warmer (typically during

261 nighttime) or cooler (typically during daytime) by several degrees as indicated by the minimum

$262\left(-9.8^{\circ} \mathrm{C}\right)$ and maximum $\left(7.7^{\circ} \mathrm{C}\right)$ values of the temperature difference (Figure $\left.4 \mathrm{~b}\right)$. On average

263 over the whole period, the conductive heat fluxes reaching the building envelope were always

264 negative, indicating heat losses from the building. However, they exhibited less diurnal

265 fluctuations than for the REF roof. The mean half hourly conductive heat flux was -5 W.m ${ }^{-2}$ 
during nighttime, increased during the morning to peak at $-1.5 \mathrm{~W} \cdot \mathrm{m}^{-2}$ in early afternoon, and

267 decreased to its nighttime value during the afternoon (Figure 2d).

268 The mean half hourly conductive heat fluxes reaching the building envelope and building 269 surface temperatures for the SI green roof did not exhibited diurnal fluctuations: the former 270 remained at around $-4.5 \mathrm{~W} \cdot \mathrm{m}^{-2}$ and the latter at around $9{ }^{\circ} \mathrm{C}$ (Figures $2 \mathrm{~d}$ and $2 \mathrm{c}$, respectively). 271 The building surface temperature exhibited also less fluctuation as shown by the $1^{\text {st }}$ and $3^{\text {rd }}$ 272 quartiles $\left(6.9^{\circ} \mathrm{C}\right.$ and $11.4^{\circ} \mathrm{C}$, respectively) and minimum and maximum $\left(3.1^{\circ} \mathrm{C}\right.$ and $14.2^{\circ} \mathrm{C}$, respectively) temperatures (Figure 4a). Over the whole period the SI green roof also exhibited

274 the warmest building surface envelope with a median temperature of $8.9^{\circ} \mathrm{C}$ (Figure $4 \mathrm{a}$ ). The 275 building surface for the SI green roof was most of the time warmer than for the REF roof: the 276 temperature difference over the whole period was $-2.6^{\circ} \mathrm{C}$ (median), typically varied between $2770.2^{\circ} \mathrm{C}$ to $-5.4^{\circ} \mathrm{C}\left(1^{\text {st }}\right.$ and $3^{\text {rd }}$ quartiles), and could reach $-14.1^{\circ} \mathrm{C}$ (minimum). However, it could 278 also be cooler than for the REF roof, although it remained exceptional and typically during 279 daytime, as indicated by the maximum value of the building enveloped temperature difference 280 reaching $7.6^{\circ} \mathrm{C}$ (Figure $4 \mathrm{~b}$ ).

281 Hence, huge differences has been observed concerning the impact of the green roofs on the 282 conductive heat fluxes reaching the building envelope. Nevertheless, these fluxes are also 283 closely linked with indoor temperatures, depending themselves to building users. In this study, 284 indoor environments consisted in offices and it has been hypothesis that indoor temperatures 285 were identical for each green roofs. However, since office users could control the room heating, 286 some differences could occur between indoors temperatures. The conductive heat flux $(\mathrm{G})$ 287 depends on the building envelope surface temperature difference between outdoor and indoor 288 ( $\mathrm{T}_{\text {out }}$ and $\mathrm{T}_{\mathrm{in}}$, respectively) and on the thermal transmittance $\left(\mathrm{U}_{\text {value }}\right.$ in $\left.\mathrm{W} \cdot \mathrm{m}^{-2} \cdot \mathrm{K}^{-1}\right)$ (i.e., $\mathrm{G}=\mathrm{U}_{\text {value }}$ $289 \mathrm{x}\left(\mathrm{T}_{\text {out }}-\mathrm{T}_{\text {in }}\right)$ ). Considering a $\mathrm{U}_{\text {value }}$ of $3.33 \mathrm{~W} \cdot \mathrm{m}^{-2} \cdot \mathrm{K}^{-1}$ (reported by Fokaides and Kalogirou [50] 290 for a flat and non-insulated roof made of reinforced concrete, which is comparable to the studied 
building), a change of $1^{\circ} \mathrm{C}$ of the indoor building surface envelope would lead to a change of

$2923.33 \mathrm{~W} \cdot \mathrm{m}^{-2}$ of the conductive heat flux reaching the external building envelope, which would not affect the trends observed during the experiment. In addition, the nocturnal conductive heat fluxes similar for each roofs (Figure 2d), corresponding to heat losses from the building, suggested that the indoor temperatures were identical for REF, EXT, and SI roofs.
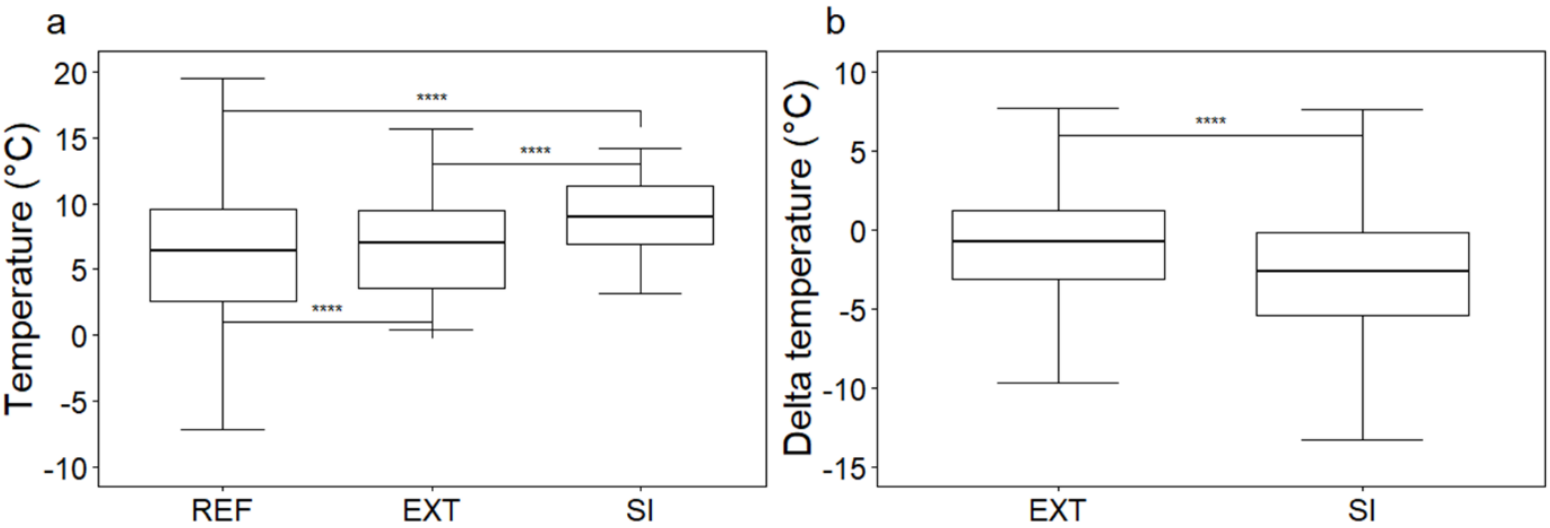

Figure 4: Boxplot statistics of (a) surface temperatures of the reference (REF) roof and temperatures at the substrate-building envelope interface for the extensive (EXT) and semiintensive (SI) roofs, and (b) half-hourly differences between surface temperature of the reference roof and temperature at the substrate-building envelope interface for the green roofs. Are also indicated the results from the Wilcoxon statistical test $(* * * *=\mathrm{p}$-value $<0.0001)$.

Although they were only interested in EXT green roofs during winter conditions, previous studies also found that the green roofs exhibited weak fluctuations of the building surface envelope temperatures under Mediterranean [37] and continental [45] climates, and less than for the conventional roofs. For instance Teemusk and Mander [40] reported during the winter period for continental climate monthly variation of daily temperature amplitudes between around $1{ }^{\circ} \mathrm{C}$ and $2.5^{\circ} \mathrm{C}$ approximately for a green roof while they reached up to $5^{\circ} \mathrm{C}$ for the conventional roof. Similarly Getter et al. [41] reported for a Midwestern U.S. climate building envelope temperature varying between $-4^{\circ} \mathrm{C}$ during nighttime and $10^{\circ} \mathrm{C}$ during daytime for a 
conventional roof whereas it only ranged from around $-1{ }^{\circ} \mathrm{C}$ to $2{ }^{\circ} \mathrm{C}$ for the green roof. These

312 largest temperature fluctuations for the conventional roof are linked with the absence of 313 substrate and vegetation layer, allowing a direct exposure of the building envelope to solar 314 radiation. It induces that the building envelope for the conventional roof rapidly warms during 315 daytime due to the fast increase of incident radiation, but also cools faster due to fast radiative 316 losses. On the contrary, the building envelope with a green roof is not directly exposed to the 317 solar radiation. The energy received at the green roof surface needs to be transferred through 318 the conductive heat flux within the substrate which is less efficient than the direct exposure to 319 sun radiation. This issue explains that the maximum building envelope temperature for the EXT 320 green roof only occurred in late afternoon while it occurred around noon for the REF roof. Yet, 321 the green roof substrate also prevents direct building envelope cooling from radiative losses. 322 The presence of substrate is therefore of a key importance for the assessment of building insulation during winter, and its thickness the main factor controlling its efficiency since 324 vegetation is sparse and weakly evapotranspirates under such conditions, whatever the kind of 325 green roof (i.e., EXT or SI) considered. Indeed, the grass transpiration under winter conditions 326 only accounts for a small part of the total evapotranspiration, between 5-20\% [51]. Hence, 327 although the vegetation densities are quite different between EXT and SI green roofs (with a 328 percentage of plant cover of approximatively $20-25 \%$ for EXT and $100 \%$ for SI, which is partly 329 composed of yellow and inactive leaves), it could be expected that the total evapotranspiration 330 is mainly driven by soil evaporation during winter conditions, which depends on atmospheric 331 conditions (identical for the two roofs) and substrate water content (always close to the field 332 capacity during the experiment). That would lead to a similar evapotranspiration for EXT and 333 SI green roof under winter condition despite the differences in terms of LAI and canopy cover, 334 as confirmed by Silva et al. [44]. 
As illustrated in Figure 5 the conductive heat fluxes within the substrate varied between -20

$\mathrm{W} \cdot \mathrm{m}^{-2}$ and $35 \mathrm{~W} \cdot \mathrm{m}^{-2}$ for the EXT green roof (Figure 5a) while it only ranged from $-10 \mathrm{~W} . \mathrm{m}^{-2}$ to $5 \mathrm{~W} . \mathrm{m}^{-2}$ for the SI green roof (Figure $5 \mathrm{~b}$ ) for the same period from 2 November to 17

338 November 2018. This trend is probably due to heat storage within the substrate which is all the 339 more important that the substrate is deep. Yet it is observed a time lag between (i) the 340 temperature difference between substrate surface and substrate-building envelope interface and 341 (ii) the conductive heat flux within the substrate for the SI green roof (Figure 5b), which did 342 not occurred for the EXT green roof (Figure 5a). Hence the thick substrate of the SI green roof 343 provides large thermal inertia. As a consequence the conductive heat fluxes reaching the 344 building envelope exhibit less fluctuation with than without a green roof, and this effect 345 increases with the substrate thickness. That issue was also found by D'Orazio et al. [42] who 346 compared EXT green roof with conventional ones.

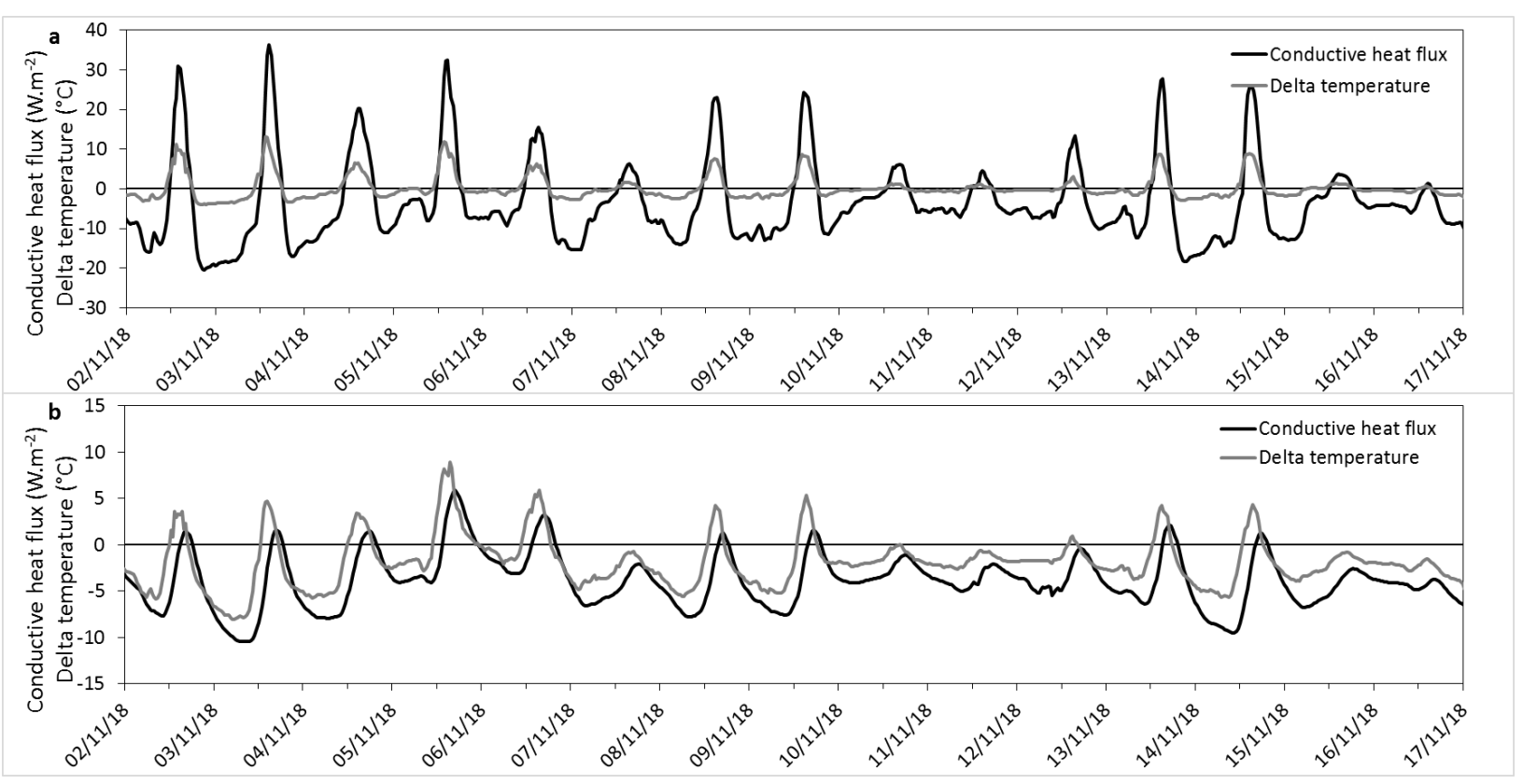

348 Figure 5: Time series of half-hourly conductive heat fluxes within the substrate and 349 temperature differences between the substrate surface and the substrate-building envelope 350 interface for the (a) extensive and (b) semi-intensive green roofs. 


\section{4 - Impact of green roofs on winter surface urban heat island}

353 The impact of the green roofs on winter surface UHI has been explored by comparing the 354 surface temperatures for the REF, EXT, and SI roofs. The surface temperatures for the REF 355 roof are those presented in the previous section and will not be described in this section.

356 Considering the whole period the EXT green roof had median surface temperature of $5.6^{\circ} \mathrm{C}$ $357\left(2^{\circ} \mathrm{C}\right.$ and $8.4^{\circ} \mathrm{C}$ for the $1^{\text {st }}$ and $3^{\text {rd }}$ quartiles, respectively), minimum and maximum surface 358 temperatures reaching $-3.9^{\circ} \mathrm{C}$ and $18.2^{\circ} \mathrm{C}$, respectively. The SI green roof had slightly warmer 359 surface temperature with median value equal to $6.2^{\circ} \mathrm{C}$ and $1^{\text {st }}$ and $3^{\text {rd }}$ quartiles of $3^{\circ} \mathrm{C}$ and $8.9^{\circ} \mathrm{C}$, 360 respectively. The minimum and maximum surface temperature were similar than for the EXT 361 green roof. Considering the whole period, the surface temperature of the SI green roof did not 362 differ significantly to the surface temperature of the REF roof while the EXT green roof is 363 cooler, as indicated by the results of the Wilcoxon statistical tests (Figure 6a). Indeed, the half364 hourly difference between surface temperatures of the REF and SI roofs typically ranged 365 between $-1.1^{\circ} \mathrm{C}$ and $0.9^{\circ} \mathrm{C}\left(1^{\text {st }}\right.$ and $3^{\text {rd }}$ quartiles $)$ with a median value of $0.2^{\circ} \mathrm{C}$ whereas this 366 difference varied between $-0.5^{\circ} \mathrm{C}$ and $1.6^{\circ} \mathrm{C}\left(1^{\text {st }}\right.$ and $3^{\text {rd }}$ quartiles $)$ with a median value of $0.8^{\circ} \mathrm{C}$ 367 for the EXT green roof (Figure 6b).

368 Huge differences occurred between surface temperature of the REF, EXT and SI roofs at the 369 daily scale (Figure 2c). The surface temperatures for both the EXT and SI green roofs exhibited 370 a similar daily evolution, following the same dynamics than the REF roof: they increased during 371 the morning to reach their maximum around noon before decreasing during the afternoon to 372 their minimum and nocturnal value. However, maximum mean half-hourly surface 373 temperatures only peaked to $8.4^{\circ} \mathrm{C}$ and $8.9^{\circ} \mathrm{C}$ for the EXT and SI green roofs, respectively, 374 while it reached $13^{\circ} \mathrm{C}$ for the REF roof. The nocturnal surface temperatures are similar between 375 the EXT and REF roofs, around $3.5-5^{\circ} \mathrm{C}$, but the SI green roof exhibited systematic slightly 376 warmer surface, around $4.5-6^{\circ} \mathrm{C}$ (Figure $2 \mathrm{c}$ ). 
377 Overall, EXT and SI green roofs only had a slight negative (i.e., cooling) effect on winter 378 surface urban heat island as reported by Teemusk and Mander [40]. However, under diurnal 379 conditions the presence of green roofs resulted in surface cooling. Although this cooling for the 380 SI green roof could be due its higher albedo compared to the REF roof, it would not be 381 consistent for the EXT green roof (its albedo being lower than those of the REF roof, warmer 382 surface would be expected). Hence, it would be probably due to low but significant 383 evapotranspiration even during winter conditions [39,44], which is comparable for EXT and SI 384 green roofs according to Silva et al. [44]. Nevertheless, the SI green roof exhibited 385 systematically warmer surface temperature, by around $1^{\circ} \mathrm{C}$, inducing that it had a positive (i.e., 386 warming) effect during the nocturnal conditions compared to the REF roof. It is probably due 387 to its thicker substrate allowing a larger heat capacity and thermal inertia and therefore a slower 388 surface cooling during nighttime.
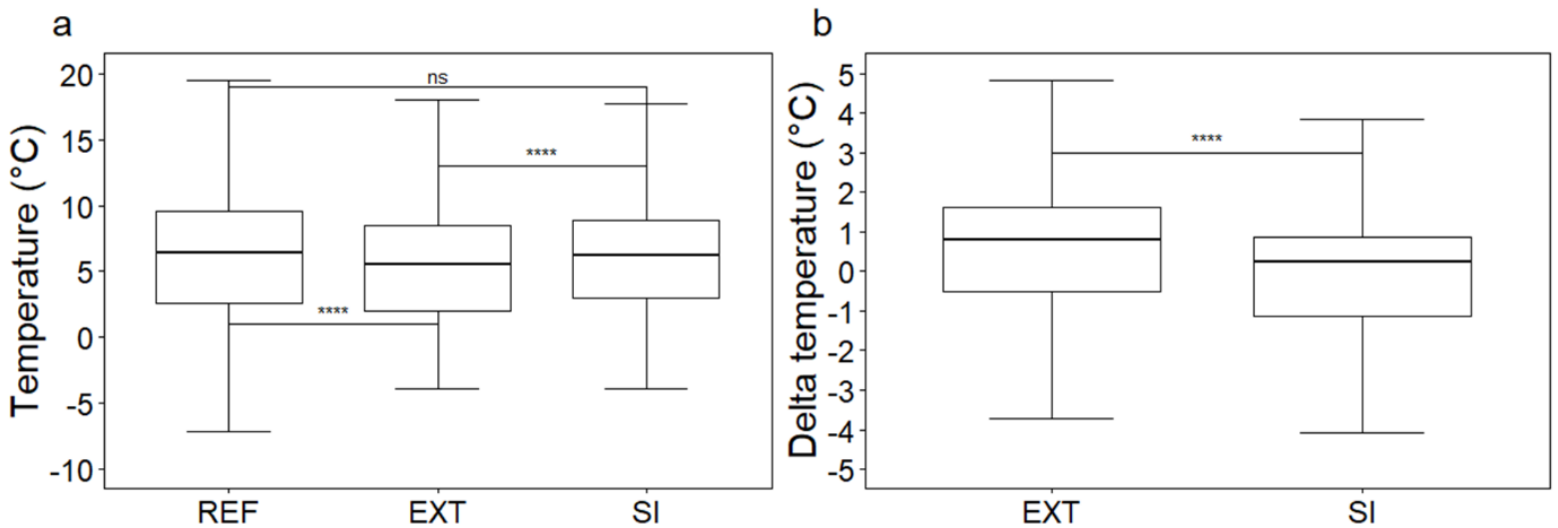

390 Figure 6: Boxplot statistics of (a) the surface temperatures of the reference (REF), extensive 391 (EXT), and semi-intensive (SI) roofs, and (b) the half-hourly differences between surface temperature of the reference roof and the surface temperature for the green roofs. Are also

393 indicated the results from the Wilcoxon statistical test $(\mathrm{ns}=\mathrm{p}$-value $>0.05, * * * *=\mathrm{p}$-value $<$ $3940.0001)$. 
This study attempted to investigate the impact of two kinds of green roofs i.e., extensive (EXT)

398 and semi-intensive (SI) green roofs, on both building insulation and surface urban heat island

399 effect under winter conditions. To this aim we compared measurements of surface and building

400 envelope temperatures as well as conductive heat fluxes reaching the external building envelope

401 with those measured on a conventional bituminous roof under identical climatic conditions.

402 While the SI green roof provides a building envelope surface warming compared to the 403 conventional bituminous roof, the EXT green roof has no clear effect on average. However, at 404 the daily scale, although the conventional roof benefits to diurnal solar radiation, and therefore surface heating, it is also exposed to important radiative heat losses during nighttime. On the contrary, green roofs provide an additional insulation layer which diminishes the daily

407 fluctuations of building envelope temperature under winter conditions whatever the kind of 408 green roof. As a consequence, the conductive heat fluxes reaching the external building envelope also suffer to more daily fluctuations for the conventional bituminous roof than for the green roofs. These effects are all the more important that the substrate is thick, owing to its 411 larger heat capacity and thermal inertia. Although it has not been quantified, it could be 412 hypothesized that the reduction of daily fluctuations of conductive heat fluxes would also 413 reduce the building energy consumption by reducing heating loads.

414 On average the green roofs only have an insignificant or slight effect on surface UHI. However 415 they provide a surface cooling during daytime due to even low but significant 416 evapotranspiration. During nighttime the EXT green roof exhibits similar surface temperature 417 than the conventional roof, while the SI green roof is warmer.

418 Therefore green roofs can be suitable urban greening solutions since they do not have negative 419 effect on surface urban heat island during winter while they provide an efficient cooling under 420 summer conditions, and provide building insulation [24,28,31,33]. 


\section{Acknowledgements}

This work was supported by a grant from Vinci Construction France. The authors also acknowledge Hacene Bouhoun-Ali for its help in the experimental set-up and data acquisition.

\section{Declaration of interest}

The authors declare that they have no known competing financial interests or personal relationships that could have appeared to influence the work reported in this paper.

\section{References}

[1] IPCC, 2014: Climate Change 2014: Mitigation of Climate Change. Contribution of Working Group III to the Fifth Assessment Report of the Intergovernmental Panel on Climate Change [Edenhofer, O., R. Pichs-Madruga, Y. Sokona, E. Farahani, S. Kadner, K. Seyboth, A. Adler, I. Baum, S. Brunner, P. Eickemeier, B. Kriemann, J. Savolainen, S. Schlömer, C. von Stechow, T. Zwickel and J.C. Minx (eds.)]. Cambridge University Press, Cambridge, United Kingdom and New York, NY, USA.

[2] W.G.V. Balchin, N. Pye, A micro-climatological investigation of Bath and the surrounding district, Q. J. Roy. Meteor. Soc. 73 (1947) 297-323.

[3] T.R. Oke, The energetic basis of the urban heat island, Q. J. Roy. Meteor. Soc. 108 (1982) $1-24$.

[4] H. Akbari, M. Pomerantz, H. Taha, Cool surfaces and shade trees to reduce energy use and improve air quality in urban areas, Sol. Energy. 70 (2001) 295-310.

[5] C. Li, J. Zhou, Y. Cao, J. Zhong, Y. Liu, C. Kang, Y. Tan, Interaction between urban microclimate and electric air-conditioning energy consumption during high temperature season, Appl. Energ. 117 (2014) 149-156.

[6] S. Vandentorren, F. Suzan, S. Medina, M. Pascal, A. Maulpoix, J.C. Cohen, M. Ledrans, Mortality in 13 French cities during the August 2003 heat wave, Am. J. Public. Health. 94 (2004) 1518-1520.

[7] M. Duneier, Ethnography, the ecological fallacy, and the 1995 Chicago heat wave, Am. Sociol. Rev. 71 (2006) 679-688.

[8] S.L. Harlan, D.M. Ruddell, Climate change and health in cities: impacts of heat and air pollution and potential co-benefits from mitigation and adaptation, Curr. Opin. Env. Sust. 3 (2011) 126-134.

[9] A.H. Rosenfeld, H. Akbari, J.J. Romm, Cool communities: Strategies for heat island mitigation and smog reduction, Energ. Buildings. 28 (1998) 51-62.

[10] C. Sarrat, A. Lemonsu, V. Masson, D. Guedalia, Impact of urban heat island on regional atmospheric pollution, Atmos. Environ. 40 (2006) 1743-1758. 
[11] G. Pigeon, D. Legain, P. Durand, V. Masson, Anthropogenic heat release in an old European agglomeration (Toulouse, France), Int. J. Climatol. 27 (2007) 1969-1981.

[12] Y. Wen, Z. Lian, Influence of air conditioners utilization on urban thermal environment, Appl. Therm. Eng. 29 (2009) 670-675.

[13] C. de Munck, G. Pigeon, V. Masson, F. Meunier, P. Bousquet, B. Tréméac, M. Merchat, P. Poeuf, C. Marchadier, How much can air conditioning increase air temperatures for a city like Paris, France?, Int. J. Climatol. 33 (2013) 210-227.

[14] F. Asdrubali, F. D'Alessandro, S. Schiavoni, A review of unconventional sustainable building insulation materials, Sustain. Mater. Technol. 4 (2015) 1-17.

[15] S. Schiavoni, F. D'Alessandro, F. Bianchi, F. Asdrubali, Insulation materials for the building sector: A review and comparative analysis, Renew. Sust. Energ. Rev. 62 (2016) 988-1011.

[16] D. Prakash, A review of heat dissipating passive cooling techniques for residential buildings at tropical region, J. Eng. Sci. Technol. 8 (2012) 2120-2140.

[17] N. Mirabella, M. Röck, M.R.M. Saade, C. Spirinckx, M. Bosmans, K. Allacker, A. Passer, Strategies to improve the energy performance of buildings: a review of their life cycle impact, Buildings 8 (2018) 105. doi:10.3390/buildings8080105.

[18] J. Yang, Q. Yu, P. Gong, Quantifying air pollution removal by green roofs in Chicago, Atmos. Environ. 42 (2008) 7266-7273.

[19] Y. Li, R.W. Babcock Jr., Green roofs against pollution and climate change. A review. Agron. Sustain. Dev. 34 (2014) 695-705.

[20] N. Dunnett, A. Nagase, R. Booth, P. Grime, Influence of vegetation composition on runoff in two simulated green roof experiments, Urban Ecosyst. 11 (2008) 385-398.

[21] E. Cristiano, R. Deidda, F. Viola, The role of green roofs in urban Water-Energy-FoodEcosystem nexus: A review. Sci. Tot. Environ. 756 (2021) 143876.

[22] U. Berardi, A.H. GhaffarianHoseini, A. GhaffarianHoseini, State-of-the-art analysis of the environmental benefits of green roofs, Appl. Energ. 115 (2014) 411-428.

[23] L.L. Peng, C.Y. Jim, Green-roof effects on neighborhood microclimate and human thermal sensation, Energies 6 (2013) 598-618.

[24] C. de Munck, A. Lemonsu, V. Masson, J. Le Bras, M. Bonhomme, Evaluating the impacts of greening scenarios on thermal comfort and energy and water consumptions for adapting Paris city to climate change, Urban Climatol. 23 (2018) 260-286.

[25] B. Raji, M.J. Tenpierik, A. van den Dobbelsteen, The impact of greening systems on building energy performance: A literature review, Renew. Sust. Energ. Rev. 45 (2015) 610-623.

[26] A. Niachou, K. Papakonstantinou, M. Santamouris, A. Tsangrassoulis, G. Mihalakakou, Analysis of the green roof thermal properties and investigation of its energy performance, Energ. Buildings 33 (2001) 719-729.

[27] N. Wong, Y. Chen, C. Ong, A. Sia, Investigation of thermal benefits of rooftop garden in the tropical environment, Build. Environ. 38 (2003) 261-270.

[28] I. Jaffal, S.E. Ouldboukhitine, R. Belarbi, A comprehensive study of the impact of green roofs on building energy performance, Renew. Energ. 43 (2012) 157-164. 
[29] L.M. Cook, T.A. Larsen, Towards a performance-based approach for multifunctional green roofs: An interdisciplinary review, Build. Environ. 188 (2021) 107489.

[30] M. Maiolo, B. Pirouz, R. Bruno, S.A. Palermo, N. Arcuri, P. Piro, The role of the extensive green roofs on decreasing building energy consumption in the Mediterranean climate, Sustainability 12 (2020) 359 .

[31] R. Kumar, S.C. Kaushik, Performance evaluation of green roof and shading for thermal protection of buildings, Build. Environ. 40 (2005) 1505-1511.

[32] H.F. Castleton, V. Stovin, S.B.M. Beck, J.B. Davison, Green roofs, building energy savings and the potential for retrofit, Energ. Buildings 42 (2010) 1582-1591.

[33] G. Qiu, H. Li, Q. Zhang, W. Chen, X. Liang, X. Li, Effects of evapotranspiration on mitigation of urban temperature by vegetation and urban agriculture, J. Integr. Agr. 12 (2013) 1307-1315.

[34] M. Eksi, D.B. Rowe, I.S. Wichman, J.A. Andresen, Effect of substrate depth, vegetation type, and season on green roof thermal properties, Energ. Buildings 145 (2017) 174-187.

[35] Y. Yang, C.I. Davidson, J. Zhang, Evaluation of thermal performance of green roofs via field measurements and hygrothermal simulations, Energ. Buildings 237 (2021) 110800.

[36] M. Santamouris, C. Pavlou, P. Doukas, G. Mihalakakou, A. Synnefa, A. Hatzibiros, P. Patargias, Investigating and analysing the energy and environmental performance of an experimental green roof system installed in a nursery school building in Athens, Greece, Energy 32 (2007) 1781-1788.

[37] J. Coma, G. Pérez, C. Solé, A. Castell, L.F. Cabeza, Thermal assessment of extensive green roofs as passive tool for energy savings in buildings, Renew. Energ. 85 (2016) 11061115 .

[38] J.T. Lundholm, B.M. Weddle, J.S. MacIvor, Snow depth and vegetation type affect green roof thermal performance in winter, Energ. Buildings 84 (2014) 299-307.

[39] R.M. Lazzarin, F. Castellotti, F. Busato, Experimental measurements and numerical modelling of a green roof, Energ. Buildings 37 (2005) 1260-1267.

[40] A. Teemusk, Ü. Mander, Greenroof potential to reduce temperature fluctuations of a roof membrane: A case study from Estonia, Build. Environ. 44 (2009) 643-650.

[41] K.L. Getter, D.B. Rowe, J.A. Andresen, I.S. Wichman, Seasonal heat flux properties of an extensive green roof in Midwestern U.S. climate, Energ. Buildings 43 (2011) 3548-3557.

[42] M. D’Orazio, C. Di Perna, E. Di Giuseppe, Green roof yearly performance: A case study in a highly insulated building under temperate climate, Energ. Buildings 55 (2012) 439451.

[43] M. Zhao, J. Srebric, Assessment of a green roof performance for sustainable buildings under winter weather conditions, J. Cent. South Univ. 19 (2012) 639-644.

[44] C.M. Silva, M.G. Gomes, M. Silva, Green roofs energy performance in Mediterranean climate, Energ. Buildings 116 (2016) 318-325.

[45] M. Squier, C.I. Davidson, Heat flux and seasonal thermal performance of an extensive green roof, Build. Environ. 107 (2016) 235-244.

[46] S. Collins, K. Kuoppamäki, D.J. Kotze, X. Lü, Thermal behavior of green roofs under Nordic winter conditions, Build. Environ. 122 (2017) 206-214. 
[47] H. Radhi, E. Assem, S. Sharples, On the colours and properties of building surface materials to mitigate urban heat islands in highly productive solar regions, Build. Environ. 72 (2014) 162-172.

[48] O. Saadatian, K. Sopian, E. Salleh, C.H. Lim, S. Riffat, E. Saadatian, A. Toudeshki, M.Y Sulaiman, A review of energy aspects of green roofs. Renew. Sust. Energ. Rev. 23 (2013) $155-168$.

[49] H. Takebayashi, M. Moriyama, Surface heat budget on green roof and high reflection roof for mitigation of urban heat island. Build. Environ. 42 (2007) 2971-2979.

[50] P.A. Fokaides, S.A. Kalogirou, Application of infrared thermography for the determination of the overall heat transfer coefficient (U-value) in building envelopes. Applied Energ. 88 (2011) 4358-4365.

[51] J.A. Nelson, O. Pérez-Priego, S. Zhou, R. Poyatos, Y. Zhang, P.D. Blanken, T.E. Gimeno, G. Wohlfahrt, A.R. Desai, B. Gioli, J.M. Limousin, D. Bonal, E. Paul-Limoges, R.L. Scott, A. Varlagin, K. Fuchs, L. Montagnani, S. Wolf, N. Delpierre, D. Berveiller, M. Gharun, L. Belilli Marchesini, D. Gianelle, L. Sigut, I. Mammarella, L. Siebicke, T.A. Black, A. Knohl, L. Hörtnagl, V. Magliulo, S. Besnard, U. Weber, N. Carvalhais, M. Migliavacca, M. Reichstein, M. Jung, Ecosystem transpiration and evaporation: Insights from three water flux partitioning methods across FLUXNET sites. Glob. Change Biol. 26 (2020) 6916-6930. 